\title{
Susceptibility of human breast epithelial cells in vitro to hormones and drugs
}

\author{
GLORIA M. CALAF \\ Center for Radiological Research, Columbia University Medical Center, New York, NY, USA; and \\ Department of Biology and Health, Faculty of Science and Research Center for the Man in the Desert, \\ University of Tarapaca, Arica, Chile
}

Received July 6, 2005; Accepted September 16, 2005

\begin{abstract}
Breast cancer is often hormone responsive with growth or regression of tumors modulated by endocrine manipulations. Estrogens are known to control the growth of many mammary carcinomas in experimental animals, and humans. Knowledge of tumor response to hormones will greatly improve the ability to plan therapy for breast cancer patients. Chemoprevention of breast cancer has been mostly aimed at reducing the rate of cell division through administration of anti-hormones. Tamoxifen has shown to be species, tissue, and cell-type specific. Cell proliferation in mammary gland occurs in a non-random fashion since there are specific compartments with varied rates of proliferation represented by the terminal end buds that are ready for differentiation into alveolar buds. The aim of this work was to study the effect of $17 ß$ estradiol as well as an antiestrogen, tamoxifen in several in vitro systems to analyze the proliferative capabilities of different kind of cells under controlled experimental conditions. Normal, benign lesions, and duct carcinomas of human breast tissues were processed for organ culture. In the case of the normal breast tissue it was enzymatically digested and culture as organoid culture as well. Several immortalized normal and malignant human breast cell lines were also used in these studies to analyze the effect of $17 ß$ estradiol, progesterone, tamoxifen and anti-progestin RU486. Both 17 B estradiol and progesterone stimulated cell proliferation whereas tamoxifen and RU486 inhibited such effect under these experimental conditions. Thus, in vitro systems allowed to analyze the proliferative capabilities of different kind of cells under controlled experimental conditions.
\end{abstract}

Correspondence to: Dr Gloria M. Calaf, Center for Radiological Research, VC11-218, Columbia University Medical Center, 630 West 168th Street, New York, NY 10032, USA

E-mail: gmc24@columbia.edu

Key words: estrogen, tamoxifen, progesterone, RU486, breast, proliferation

\section{Introduction}

Sporadic breast cancer, the most common cancer diagnosed in most Western world countries is gradually increasing in incidence. Epidemiological and clinical evidence has identified a number of risk factors for breast cancer, such as family history, age, radiation, diet and history of proliferative breast disease (1-4). When the age-specific curve was examined for breast cancer, it was found that the initial cases occur in early adulthood, and the incidence rate increases sharply with age until menopause, when it slows dramatically. It is a classical model of hormone-dependent malignancy. Such evidence indicate that breast cancer risk is associated with prolonged ovarian function that results in elevated circulating levels of steroid hormones. Principal among these is $17 ß$ estradiol, which is associated with important risk factors, early onset of menarche and late menopause, hormone replacement therapy and postmenopausal obesity as well as with history of proliferative breast disease inducing greater cancer incidence (1). Breast cancer does not develop in the absence of ovaries and ovariectomy causes regression of established malignancies in experimental animal models. Thus, it has been reported that estrogens can induce mammary cancer (5). $17 ß$ estradiol induced in rodents a low incidence of mammary tumors after a long latency period, and only in presence of an intact pituitary axis, with induction of pituitary hyperplasic or adenomas and hyperprolactinemia. $17 \AA$ estradiol is considered the primary mitogen for breast tissue (6). Prevention would be the most efficient way of eradicating this disease. Chemoprevention of breast cancer has been mostly aimed at reducing the rate of cell division through administration of anti-hormones (7). A clinical trial demonstrated that the antiestrogen tamoxifen reduces the incidence of breast cancer in women at high risk of developing the disease (8). The non-steroidal antiestrogen tamoxifen (ICI 46,474, Nolvadex) entered clinical trials in 1971 (9). Tamoxifen has been also used based on the concept of adjuvant therapy that started after the removal of the primary tumor in order to control micrometastases before recurrence and death. Tamoxifen, with a long serum half-life, good efficacy, and lack of reported side effects, was the ideal choice as and adjuvant treatment. The initial studies used tamoxifen for up to 5 years (10), with a later decision taken to extend the treatment indefinitely (11). This overall success of adjuvant tamoxifen therapy was recently evaluated in an 
overview analysis of randomized clinical trials (12). A survival advantage is conferred by tamoxifen treatment of postmenopausal node-positive women, but not of premenopausal women. On the other hand, a clinical trial demonstrated that the antiestrogen, tamoxifen reduced the incidence of breast cancer in women at high risk of developing the disease (13-16).

Mifepristone, 17ß-hydroxy-11ß-(4-dimethylaminophenyl)$17 \alpha$-(prop-1-ynyl)-estra-4, 9-dien-3-one, is derived from the estrane progestins (RU486). To date it is used for early termination of pregnancy, among others, due to its unique properties (17). It is an orally active synthetic steroid with antiprogesterone and glucocorticoid activities. RU486 acts at the receptor level, binding strongly to the progesterone and glucocorticoid receptors (18). This drug acts upon progesterone receptor and on the expression of the uteroglobin gene in the rabbit endometrium (19). It is a potent antiprogesteterone and glucocorticoid. This substance like the progesterone enters target cells and reaches its receptor; however, it interacts differently from progesterone and may produce different conformational changes in the receptor. By occupying the progesterone receptor in the nucleus, progesterone modifies the receptor's shape, enabling it to bind to chromatin, and this binding leads to gene transcription and protein synthesis (20). The complex of mifepristone with the progesterone receptor inhibits transcription resulting in the down-regulation of progesterone-dependent genes $(20,21)$.

Although estrogens have been shown to play a central role in breast cancer development, the cell proliferation capability on human breast epithelial cells should be analyzed more extensively. To get information on the susceptibility of effects of hormones and drugs to alter breast cancer, in vitro models, utilizing different kind of cells at different stages of the neoplastic process, provide a unique opportunity for studying carcinogenesis. Thus the aim of this work was to study cell proliferation in normal, benign lesions, malignant and immortalized tumorigenic and non-tumorigenic immortalized human breast epithelial cells.

\section{Materials and methods}

Effect of $17 \beta$ estradiol on DNA synthesis of normal breast samples in organ cultures. Normal breast tissue samples were obtained from 8 women who underwent breast surgery from reduction mammoplasties. The samples were immediately placed in chilled holding medium (Medium 199, M199, Gibco, Grand Island, NY) and cultured for 5 days. All biopsy specimens were individually cultured as explants. Each specimen was cut into $1 \mathrm{~mm}^{3}$ explants and placed at random in small Falcon disposable Petri dishes containing $3 \mathrm{ml}$ of M199 (Earle's Base, Difco Labs, Detroit, MI) supplemented with penicillin G (Nutritional Biochemical Corp., OH) (50 IU/ $\mathrm{ml}$ ). The large number of randomly selected small explants per group provides reasonable assurance that an equal quantity of epithelium was distributed among the groups. Each biopsy specimen was divided into two groups, i.e., a control and experimental group. Group I contained $5.0 \mu \mathrm{g} / \mathrm{ml}$ bovine pancreas insulin and $1.0 \mu \mathrm{g} / \mathrm{ml}$ hydrocortisone; group II contained in addition $0.05 \mu \mathrm{g} / \mathrm{ml} 17 ß$ estradiol (Sigma Chemical Co., St. Louis, MO). The DNA labelling index (DNA-LI) was studied by adding $\left[{ }^{3} \mathrm{H}\right]$ methyl thymidine (specific activity $20 \mu \mathrm{C} / \mu \mathrm{mol}$, Du Pont New England Nuclear Products, Boston, MA) was added to the culture medium at a concentration of $2.0 \mu \mathrm{Ci} / \mathrm{ml}$ for $4 \mathrm{~h}$ before culture termination. It was calculated by counting the number of labeled epithelial cells from alveoli present in the lobules (ABs) and terminal end buds (TEBs). Results were expressed as labeled cells/100 cells.

Effect of $17 \beta$ estradiol on DNA synthesis of cells derived from normal breast samples in organoid cultures. Mammary gland tissue was processed by enzymatic digestion studies to measure cell proliferation of TEBs and ABs present in the tissues. The breast tissue was washed in media solution serum-free media and digested with type IV collagenase $(250 \mathrm{U} / \mathrm{ml})$, hyaluronidase $(100 \mathrm{U} / \mathrm{ml}), 10 \%$ fetal calf serum and fungizone $(0.25 \mu \mathrm{g} / \mathrm{ml})$ in medium RPMI. The tissue was digested at $37^{\circ} \mathrm{C}$ for $6-24 \mathrm{~h}$ with constant shaking at $80 \mathrm{rpm}$ to yield a suspension of intact structures. Then tissue was passed through 90-200 $\mu \mathrm{m}$ filters, washed for $2 \mathrm{~h}$ to obtain clean structures, named organoids (22). Such structures were TEBs (that cross $90 \mu \mathrm{m}$ filters) and lobules (ABs) (that cross $200 \mu \mathrm{m}$ filters). The digestion of breast tissue yielded small explants containing such structures to be used to determine the effect of estrogen on DNA-LI after 5 days in culture. Organoids from TEBs were further enzymatically digested and filtered though $51 \mu \mathrm{m}$ filters, centrifuged at 1,200 x g for $10 \mathrm{~min}$ and washed for $2 \mathrm{~h}$ to obtain small epithelial structures as small organoids from which cells grew as monolayer. To determine the effect of 173 estradiol on DNA-LI of such cells structures were placed into 60-mm diameter disposable Petri dish (Falcon Plastic, Los Angeles, CA) and cultured for 5 days containing $2.0 \mathrm{ml} \mathrm{M} 199$ with antibiotic-antimycotic mixture (Gibco, Grand Island, NY) and enriched with bovine pancreas insulin $(5 \mu \mathrm{g} / \mathrm{ml})$, hydrocortisone $(1 \mu \mathrm{g} / \mathrm{ml})$ and $10 \%$ fetal calf serum. Cultures were maintained in a $37^{\circ} \mathrm{C}$ incubator in a moist atmosphere of $5 \% \mathrm{CO}_{2}$ in air for 14 days and then treated with $17 ß$ estradiol for 5 days. Group I, control; group II contained in addition $0.001 \mu \mathrm{g} / \mathrm{ml} 17 \beta$ estradiol (Sigma Chemical Co.). The steroid hormone was dissolved in ethanol which concentration in the medium did not exceed $0.01 \%$. Sterile $\left[{ }^{3} \mathrm{H}\right]$ methyl thymidine (specific activity $20 \mu \mathrm{Ci} / \mu \mathrm{mol}$, Du Pont New England Nuclear Products) was added to the culture medium at a concentration of $2.0 \mu \mathrm{Ci} / \mathrm{ml}$ for $4 \mathrm{~h}$ before culture termination. Triplicate dishes from each group were removed and collected for autoradiographic studies. The DNALI as previously reported (23-25) was calculated by counting the number of labeled cells/100 cells after 5 days of culture.

Effect of $17 \beta$ estradiol on DNA synthesis of benign breast lesions (fibroadenomas and fibrocystic disease) in organ culture. Benign lesions derived from eight premenopausal women were cultured for 5 days. All biopsy specimens were individually cultured as explants as it was explained above for normal breast samples in organ culture. Each biopsy specimen was divided into two experimental groups. Group I contained $5.0 \mu \mathrm{g} / \mathrm{ml}$ bovine pancreas insulin and $1.0 \mu \mathrm{g} / \mathrm{ml}$ hydrocortisone; group II contained in addition $0.05 \mu \mathrm{g} / \mathrm{ml}$ $17 ß$ estradiol (Sigma Chemical Co.). The DNA-LI was studied by adding [ $\left.{ }^{3} \mathrm{H}\right]$ methyl thymidine (specific activity $20 \mu \mathrm{C} / \mu \mathrm{mol}$, Du Pont New England Nuclear Products) was added to the 
culture medium at a concentration of $2.0 \mu \mathrm{Ci} / \mathrm{ml}$ for $4 \mathrm{~h}$ before culture termination. It was calculated by counting the number of labeled epithelial cells and fibroblast from fibrocystic disease and fibroadenomas of explants after 5 days of culture. Results were expressed as labeled cells/100 cells.

Effect of $17 \beta$ estradiol and tamoxifen on DNA synthesis of malignant breast samples in organ culture. Breast tumor biopsy specimens (ductal carcinoma) from 8 premenopausal women were placed in a chilled holding medium and delivered to the laboratory within $1 \mathrm{~h}$. The biopsy specimens were immediately and carefully cut while immersed in the holding medium, taking care to avoid excessive crushing and shearing forces in preparing the explants. Each specimen was cut into fragments, called explants, then were pooled and placed in Falcon disposable Petri dishes, which were placed in an incubator at $37^{\circ} \mathrm{C}$ continuously infused with gas $95 \% \mathrm{O}_{2}: 5 \%$ $\mathrm{CO}_{2}$ ) and the atmosphere was water-saturated. All biopsy specimens were individually cultured; explants were never combined. The large number of randomly selected small explants provided assurance randomly selected small explants provided assurance of an equal distribution among the groups. Group I through IV contained $5.0 \mu \mathrm{g} / \mathrm{ml}$ bovine pancreas insulin and $1.0 \mu \mathrm{g} / \mathrm{ml}$ hydrocortisone. Group II contained in addition $0.05 \mu \mathrm{g} / \mathrm{ml} \mathrm{17ß} \mathrm{estradiol} \mathrm{(Sigma} \mathrm{Chemical} \mathrm{Co.);}$ group III contained $0.05 \mu \mathrm{g} / \mathrm{ml}$ of tamoxifen and group IV contained $0.05 \mu \mathrm{g} / \mathrm{ml} 17 ß$ estradiol and $0.05 \mu \mathrm{g} / \mathrm{ml}$ tamoxifen. All hormones were purchased from Sigma Chemical Co. The DNA-LI was studied by adding $\left[{ }^{3} \mathrm{H}\right]$ methyl thymidine (specific activity $20 \mu \mathrm{Ci} / \mu \mathrm{mol}$ ) to the culture medium at a concentration of $2.0 \mu \mathrm{Ci} / \mathrm{ml}$ for $4 \mathrm{~h}$ before culture termination. It was calculated by counting the number of labeled epithelial cells of explants after 5 days of culture. Results were expressed as labeled cells/100 cells.

Effect of $17 \beta$ estradiol and tamoxifen on cell proliferation of human breast epithelial cell lines. To determine the effect of $17 ß$ estradiol and tamoxifen on cell proliferation of breast epithelial cell lines the following cell lines were used in these studies: a) MCF-10 cell line, b) clone D3, c) clone D3-3R, and d) MCF-7 cell lines. a) The immortalized human breast epithelial normal cell line MCF-10F is an immortal cell line that arose from a mortal diploid mammary epithelial cell line derived from a subcutaneous mastectomy performed in a 36-year-old women (26). This cell line has morphological characteristics of normal breast epithelial cells, such as dome formation in confluent cultures; epithelial morphology, threedimensional growth in collagen gel (26-28). Furthermore, these cells depend upon hormones and growth factors for their growth in vitro. The cells are anchorage-dependent, noninvasive, non-tumorigenic in the SCID and nude mice. It has been cultured for $>100$ populations doublings. The present study was conducted using cells in their 90th passage and they retained all the characteristics of the normal epithelium in vitro, including anchorage-dependence, non-invasiveness and non-tumorigenicity in nude mice. The cells were cultured in Dulbecco's modified Eagle's medium (DMEM)/F-12 (1:1) supplemented with $10 \%(\mathrm{v} / \mathrm{v})$ horse serum (Biofluids Inc., Rockville, MD). The medium was supplemented with 100 units $/ \mathrm{ml}$ penicillin, $100 \mu \mathrm{g} / \mathrm{ml}$ streptomycin, $1 \%$ (v/v) $0.2 \mathrm{M}$
L-glutamine (all from Gibco), $10 \mu \mathrm{g} / \mathrm{ml}$ insulin (Life Technologies, Grand Island; NY), $0.5 \mu \mathrm{g} / \mathrm{ml}$ hydrocortisone (Sigma), $0.02 \mu \mathrm{g} / \mathrm{ml}$ epidermal growth factor (Collaborative Research, Bedford, MA). The plating efficiency of the cells was $\sim 55-60 \%$, with an average population doubling time of $13 \mathrm{~h}$. The $17 \AA$ estradiol, tamoxifen, progesterone and RU486 were subjected to several doses (from $10^{-10}$ to $10^{-6} \mathrm{M}$ ); b) MCF-10F was transformed by the carcinogen DMBA (Eastman Kodak, Rocherster, NY), $1.0 \mu \mathrm{g} / \mathrm{ml}$ for $24 \mathrm{~h}$ (29). These cells gave rise to colonies in agar-methocel which were isolated and expanded, named clone D3. These cells were not tumorigenic; c) D3-3R was obtained by irradiation of D3 with 3 Gy of $\gamma$ rays, named clone D3-3R; d) MCF-7 cell line, derived from a human breast carcinoma, was used in this study (ATCC, HTB-22) and it is very tumorigenic (30). There were 4 groups to determine cell proliferation of MCF-10F, clone D3, clone D3-R and MCF-7 cell lines. Group I: cells were cultured in the absence of $17 \AA$ estradiol and tamoxifen. Group II: cells were cultured on the presence of $17 ß$ estradiol at $10^{-8} \mathrm{M}$ (Sigma Chemical Co.). Group III: cells were cultured in the presence of tamoxifen at $10^{-6} \mathrm{M}$ and group IV: cells were cultured in medium that contained 173 estradiol and tamoxifen.

Effect of progesterone and RU486 on cell proliferation of human breast epithelial cell lines. There were 4 groups to determine cell proliferation the effect of progesterone and RU486 on MCF-10F, clone D3, clone D3-R and MCF-7 cell lines. Group I: cells were cultured in the absence of progesterone and RU486. Group II: cells were cultured on the presence of progesterone (Sigma Chemical Co.) that was added to the culture medium at $10^{-9} \mathrm{M}$. Group III: cells were cultured in the presence of RU486 at $10^{-9} \mathrm{M}$ and group IV: cells were cultured in media that contained both substances. In both experimental designs $1 \times 10^{5}$ cells from the various exponentially growing cultures were plated into T25 dishes. At each time point studies, triplicate dishes from each group were trypsinized and the total number of cells per dish was determined by trypan blue exclusion assay. Cells were counted after 10 days. Significance of difference between mean values of all experiments such as normal, benign and malignant tissues as well as cell lines was analyzed by randomized block analysis of variance and Tukey's test.

\section{Results}

The different experimental designs on the effect of 173 estradiol on cell proliferation on normal breast tissue system showed that human breast cells were stimulated by the direct effect of $17 ß$ estradiol in a variety of in vitro experimental models. In those tissues where TEBs were present with 173 estradiol significantly $(\mathrm{P}<0.05)$ increased DNA synthesis, as seen by DNA-LI in comparison to control group as seen in Fig. 1A. However, the DNA-LI values of cells present in lobules were not significantly different from the control. Representative images of labelled cells in lobules, alveoli and ducts in the explants can be seen in Fig. 1B.

Cells derived from the organoid culture system obtained by enzymatic isolation of structures present in normal breast from reduction mammoplasties grew as patches of cells. Results of 

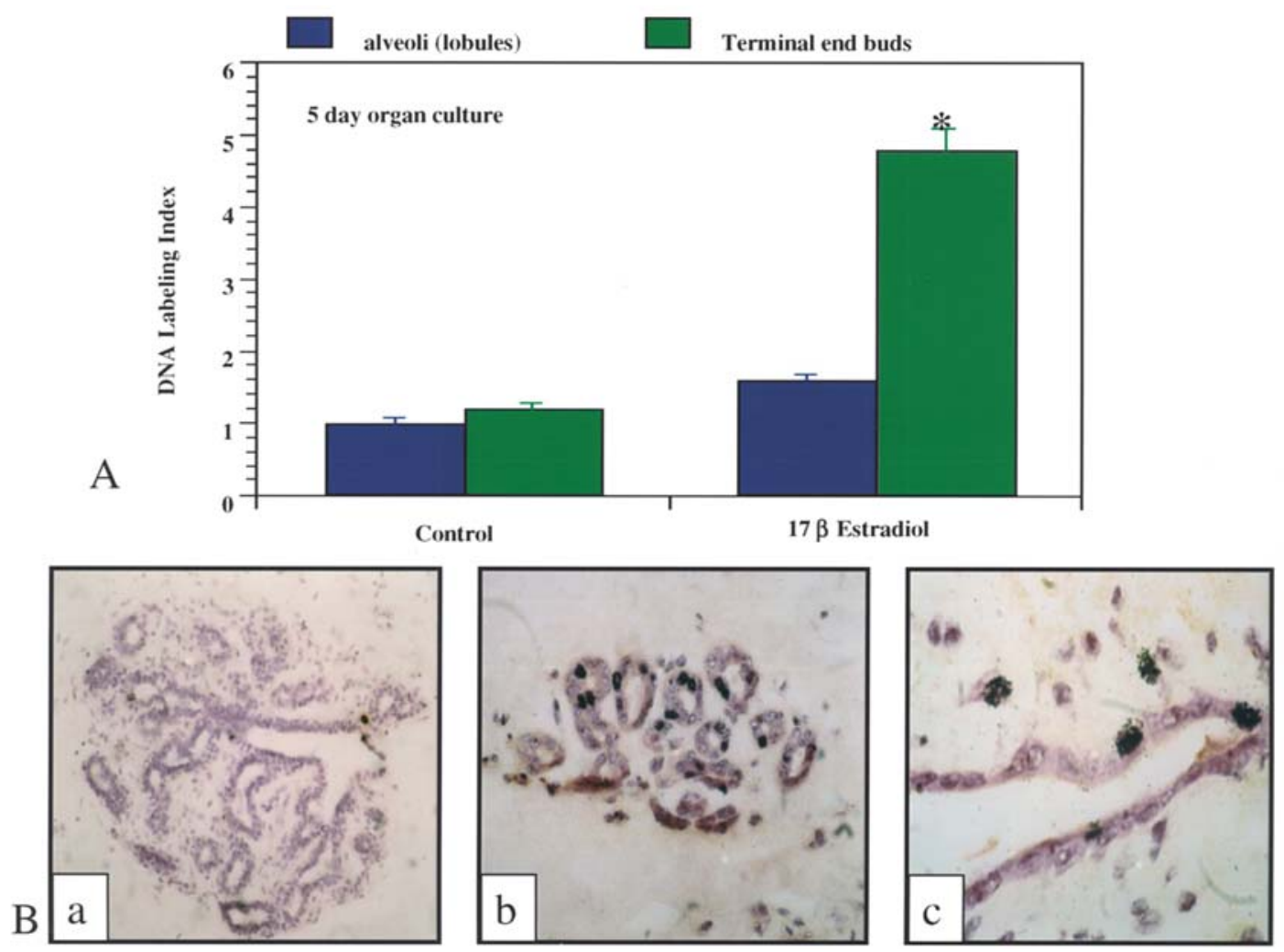

Figure 1. (A) The bars represent the mean \pm SE of the effect of $17 B$ estradiol treatment on DNA-LI in structures of normal human breast tissues in organ culture. Control: lobules versus TEBs: non-significant difference. $17 B$ estradiol-treated TEBs versus $17 B$ estradiol-treated lobules: $\mathrm{P}<0.05$. (B) Normal breast structures that correspond to lobule (a), alveoli (b) and duct (c). Hematoxylin-eosin (x400).

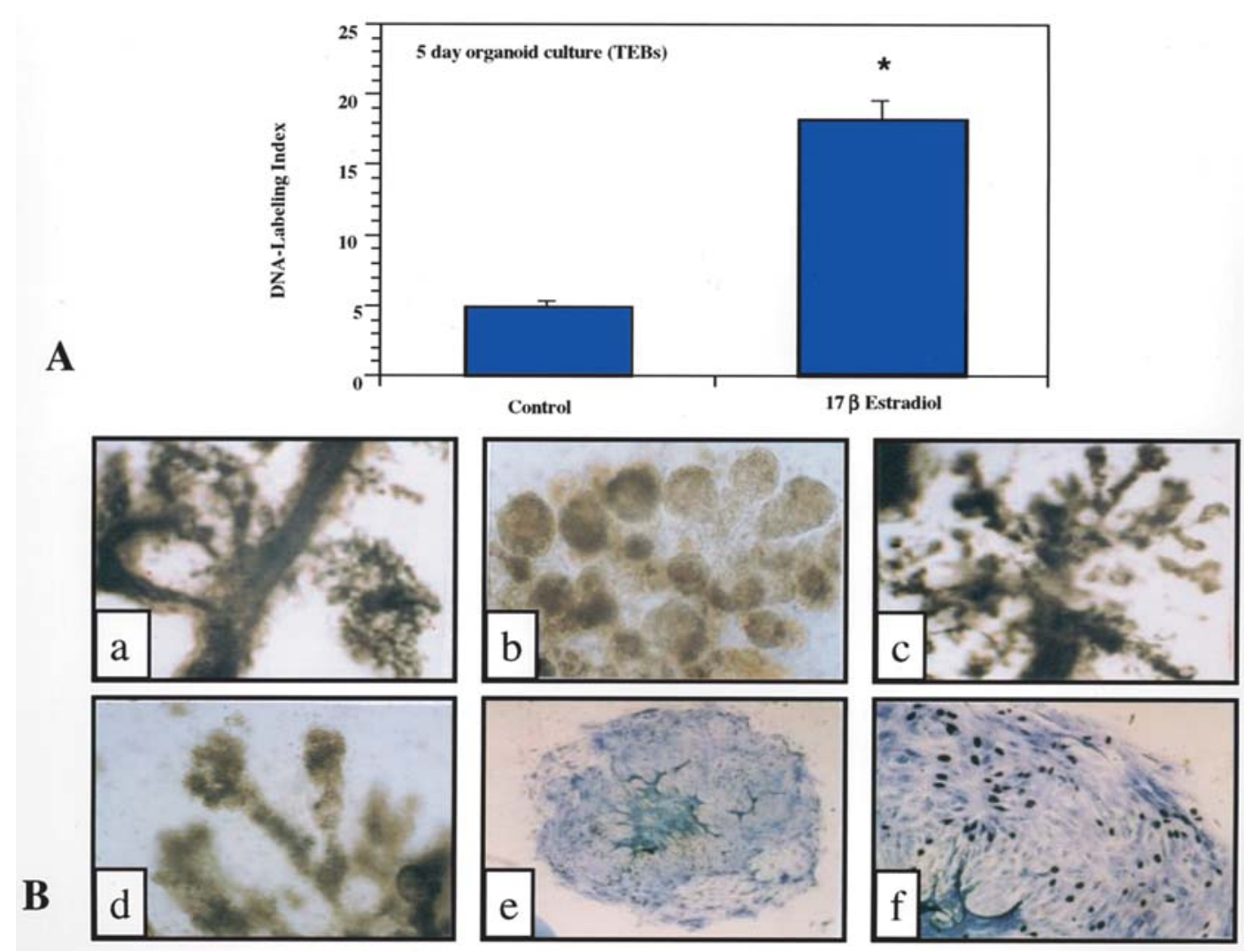

Figure 2. (A) The bars represent the mean $\pm \mathrm{SE}$ of the effect of $17 ß$ estradiol treatment on DNA-LI in structures of TEBs from normal breast derived from reduction mammoplasties. (B) Structures of normal breast from breast reduction mammoplasties composed of a main lactiferous duct, which begin to cleave into ABs forming lobules ( $a, x 350$ ). Higher magnification of lobule found in structures of (a) $(b, x 400)$. Structures of normal breast from breast reduction mammoplasties composed of a main lactiferous duct, which begin to cleave into TEBs (c, x350). Higher magnification of TEBs found in structures (d, x400). Colony derived from TEBs can be seen in low magnification (e) and higher magnification (f). 
DNA-LI in such tissues corroborated the stimulatory effect of $17 ß$ estradiol when comparison to control was done. The effect of $17 ß$ estradiol treatment on DNA-LI determined in structures of TEBs from normal breast reduction mammoplasties is represented in the bars representing the mean $\pm \mathrm{SE}$ (Fig. 2A). Those tissues derived from TEBs treated with 173 estradiol significantly $(\mathrm{P}<0.05)$ increased DNA synthesis, as seen by DNA-LI in comparison to control group as seen in Fig. 2A. However, cells derived from lobules did not grow in culture. Structures of normal breast obtained from breast reduction mammoplasties are composed of a main lactiferous duct, which begin to cleave into ABs forming lobules (Fig. $2 \mathrm{Ba}$ ), where a low magnification of two lobules can be appreciated. A higher magnification of the lobules found in structures of the previous picture is illustrated in Fig. $2 \mathrm{Bb}$. The structures beginning to cleave into TEBs can be as seen in Fig. 2Bc. High magnification of TEBs is shown in structures Fig. 2Bd. Colony derived from TEBs is shown in low magnification in Fig. 2Be and higher magnification in Fig. 2Bf.

To study the role of $17 ß$ estradiol on cell proliferation on proliferative lesions, that is benign diseases, DNA synthesis was determined in organ culture system, that is explants derived from fibrocystic disease and fibroadenomas. Such system showed that $17 ß$ estradiol significantly $(\mathrm{P}<0.05)$ increased DNA-LI of epithelial cells as well as fibroblasts of fibrocystic disease lesions after 5-day culture in comparison to control cultures (Fig. 3A). However, when compared with fibroblasts and epithelial cells present in tissues derived from fibroadenomas such cells showed very similar trend to those for fibrocystic disease, but did not reach significance (Fig. 3B). Representative images of tissues derived from fibroadenoma can be seen in Fig. 3C.

The effect of $17 ß$ estradiol and the drug tamoxifen on cell proliferation, i.e., on DNA synthesis was studied on ductal carcinoma of breast malignant lesions after 5-day cultures. It was found that $17 ß$ estradiol significantly $(\mathrm{P}<0.05)$ increased DNA-LI (Fig. 4A) and $\left[{ }^{3} \mathrm{H}\right]$ thymidine incorporation into DNA (Fig. 4B) in comparison to control. However, tamoxifen and combination of $17 ß$ estradiol and tamoxifen significantly $(\mathrm{P}<0.05)$ inhibited such effect in comparison to 173 estradioltreated samples. There was no significant difference between either tamoxifen alone and combination of $17 ß$ estradiol and tamoxifen and control group. Representative image of an explant of a carcinoma treated with $17 ß$ estradiol and tamoxifen can be observed in Fig. 4C, respectively. The cells treated with the drug were significantly altered.

It was of interest to compare the effect of $17 ß$ estradiol and tamoxifen on cell proliferation of several cell lines: both immortalized normal and malignant epithelial human breast cell lines. The immortalized MCF-10F cells grow as a contactinhibited monolayer with a population doubling time of $\sim 13 \mathrm{~h}$ (31). At confluence, these cells had a saturation density of $\sim 10 \times 10^{6}$ cells $/ 60 \mathrm{~mm}$ dish. Addition of 173 estradiol at $10^{-8} \mathrm{M}$ and tamoxifen at $10^{-6}$ dose, respectively gave the best doses to be used in further experiments (Fig. 5A and B, respectively). Fig. 5C-F show the effects of 173 estradiol and tamoxifen on total cell number per dish after 10 days in culture of MCF-10F (Fig. 5C), clone D3 (Fig. 5D), clone D3-3R (Fig. 5E) and MCF-7 (Fig. 5F) cell lines. It was found that $17 ß$ estradiol significantly $(\mathrm{P}<0.05)$ increased cell proliferation in comparison to control. However, tamoxifen and combination of both in all the cell lines significantly $(\mathrm{P}<0.05)$ inhibited such effect in comparison to $17 ß$ estradiol treated cultures. There was non-significant difference between tamoxifen and control. The clone D3 was stimulated by $17 \AA$ estradiol at $10^{-8} \mathrm{M}$ (4-fold increase) and tamoxifen inhibited such growth at $10^{-6} \mathrm{M}$ in the same magnitude in comparison to control. There was non-significant difference between tamoxifen alone, tamoxifen combined with $17 \beta$ estradiol and control group. The clone D3-3R was stimulated by $17 \mathrm{~B}$ estradiol at $10^{-8} \mathrm{M}$ (10-fold increase) and tamoxifen inhibited such growth at $10^{-6} \mathrm{M}$ in comparison to control. There was non-significant difference between tamoxifen and $17 \mathrm{~B}$ estradiol plus tamoxifen treated group. $17 \mathrm{~B}$ estradiol at $10^{-8} \mathrm{M}$ (1.4-fold increase) stimulated MCF-7 cell line and tamoxifen inhibited such growth at $10^{-6} \mathrm{M}$ (2-fold increase) in comparison to control. There was nonsignificant difference between tamoxifen combined with $17 \AA$ and control group.

To study the effect of progesterone and RU486 on cell proliferation on several cell lines, progesterone at $10^{-9} \mathrm{M}$ and RU486 at $10^{-9}$ dose, respectively gave the best doses to be used in further experiment (Fig. 6A and B, respectively). In Fig. 6C-F can be observed the effects of both substances on total cell number per dish after 10 days in culture of MCF-10F (Fig. 6C), clone D3 (Fig. 6D), clone D3-3R (Fig. 6E) and MCF-7 (Fig. 6F) cell lines. It was found that progesterone significantly $(\mathrm{P}<0.05)$ increased cell proliferation in comparison to control. However, RU486 and combination of both in all the cell lines significantly $(\mathrm{P}<0.05)$ inhibited such effect in comparison to progesterone. There was non-significant difference between RU486 and combination of both in comparison to control. The clone D3 was stimulated progesterone at $10^{-9} \mathrm{M}$ (2-fold increase) and RU486 inhibited such growth at $10^{-9} \mathrm{M}$ in the same magnitude in comparison to control. There was non-significant difference between RU486 alone, RU486 combined with progesterone and control group. The clone D3-3R was stimulated by progesterone at $10^{-9} \mathrm{M}$ (7-fold increase) and RU486 inhibited such growth at $10^{-9} \mathrm{M}$ in comparison to control. There was non-significant difference between RU486 and progesterone plus RU486-treated group. Progesterone at $10^{-9} \mathrm{M}$ (2.6-fold increase) stimulated MCF-7 cell line and RU486 inhibited such growth at $10^{-9} \mathrm{M}$ (2.2-fold increase) in comparison to control. There was non-significant difference between RU486 nor combined with progesterone and control group.

\section{Discussion}

The present studies showed that human breast epithelial cells were stimulated by $17 ß$ estradiol in a variety of in vitro experimental systems. Such stimulation was indicated by increased cell proliferation in comparison to cultures lacking this hormone. Organ as well as and organoid-culture system, i.e., structures derived from enzymatic isolation of normal breast tissue removed from female patients subjected to reduction mammoplasties, showed that $17 ß$ estradiol increased DNA synthesis in TEBs in comparison to controls. However, DNA-LI values of the $17 ß$ estradiol-treated group derived from lobules from the same specimen was not different from the control. Such stimulation was corroborated with those 

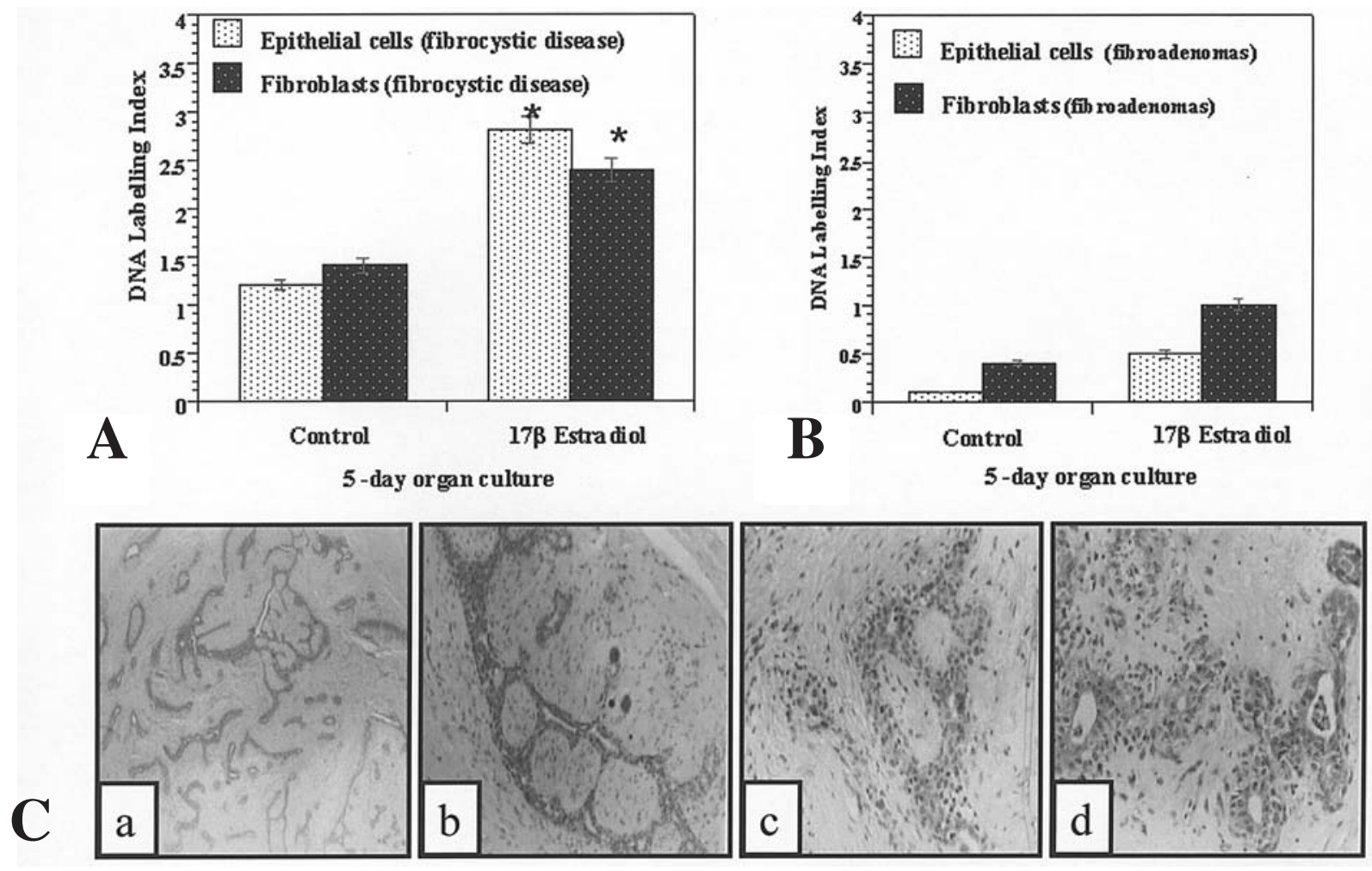

Figure 3. (A) The bars represent the mean \pm SE of DNA-LI of epithelial cells and fibroblasts present in benign (fibrocystic disease) lesions of human breast $17 \mathrm{~B}$ estradiol-treated tissues in organ culture in comparison to control. Experimental versus control: ${ }^{*} \mathrm{P}<0.05$. (B) The bars represent the mean $\pm \mathrm{SE}$ of the effect of $17 \mathrm{~B}$ estradiol on DNA-LI of epithelial cells and fibroblasts present in benign (fibroadenoma) lesions of human breast 17ß estradiol-treated tissues in organ culture in comparison to control. Experimental group versus control: non-significantly different. (C) Benign lesions of human breast tissues in organ cultures can be seen in (a-d), corresponding to intracanalicular fibroadenoma (hematoxylin-eosin; a, x40; b, x100; c, x320; d, x400).
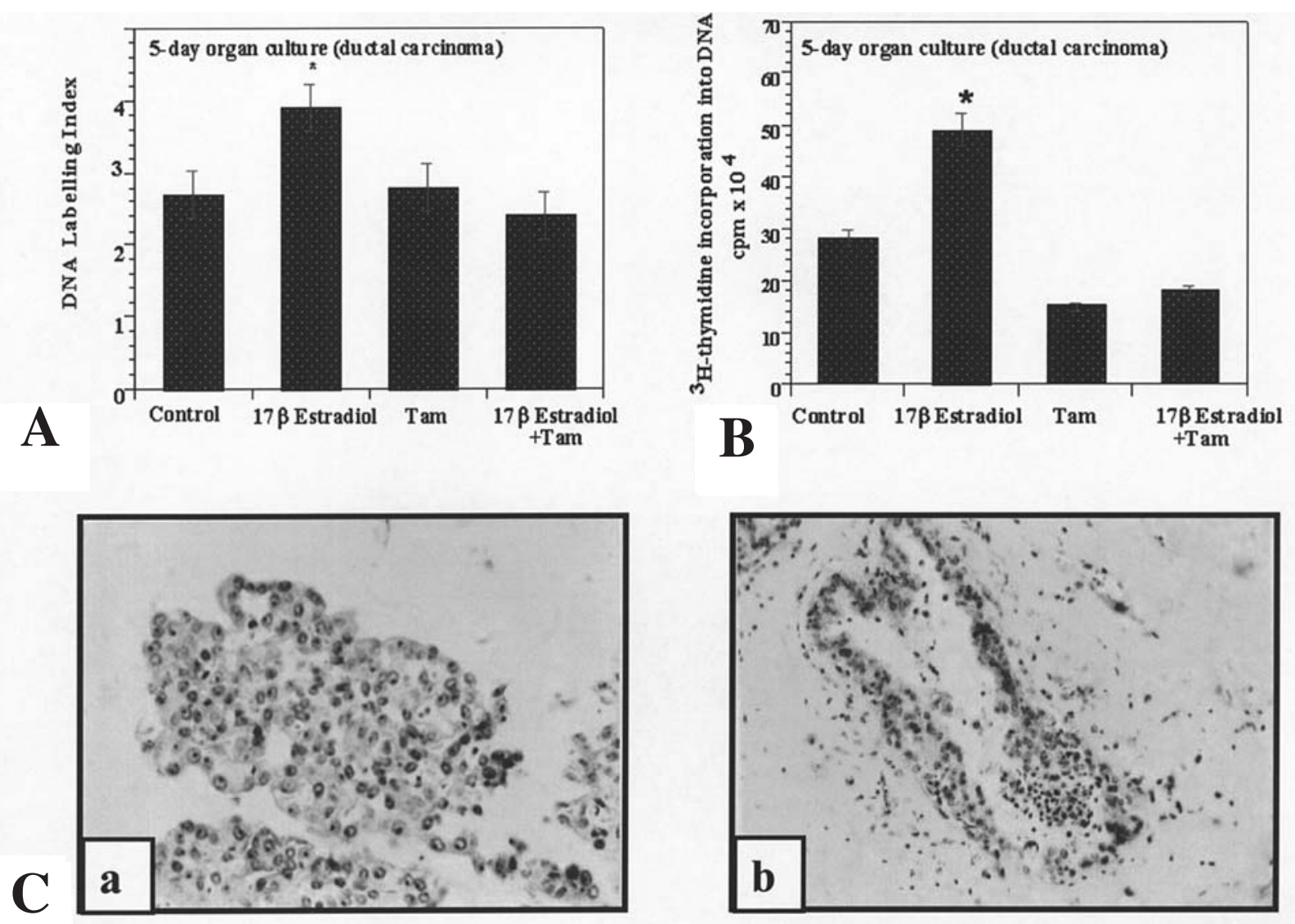

Figure 4. (A) The bars represent the mean $\pm \mathrm{SE}$ of the effect of $17 \mathrm{~B}$ estradiol and tamoxifen (Tam) on DNA-LI: (A) and $\left[{ }^{3} \mathrm{H}\right]$ thymidine incorporation into DNA $\left(\mathrm{cpm} \times 10^{3}\right)(\mathrm{B})$ of ductal carcinomas in 5-day organ culture. $17 ß$ estradiol versus control: ${ }^{*} \mathrm{P}<0.05$. Tam, $17 ß$ estradiol + Tam versus control: non-significant difference. (C) Effect of $17 \mathrm{~B}$ estradiol on cell proliferation of lobules (a) and effect of tamoxifen (b) on malignant lesions of human breast tissues in organ cultures in 5-day organ culture. Hematoxylin-eosin (x400). 


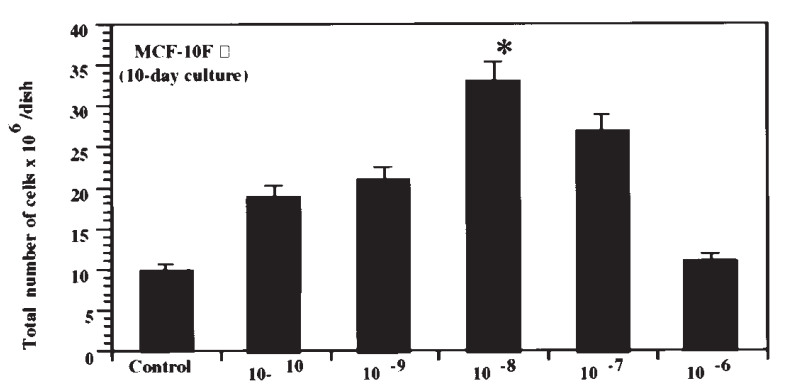

A

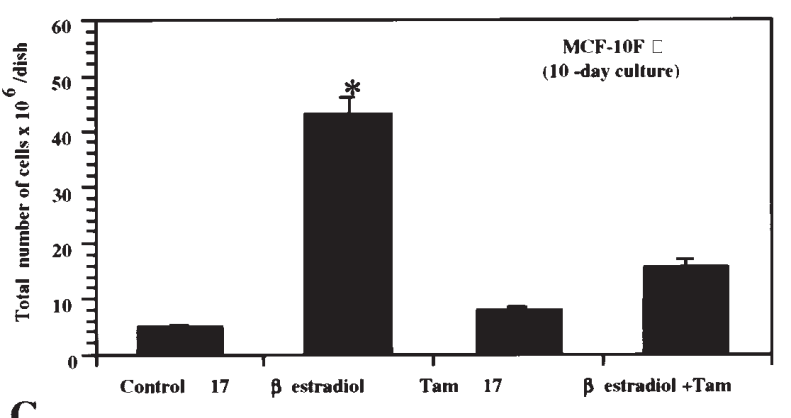

C

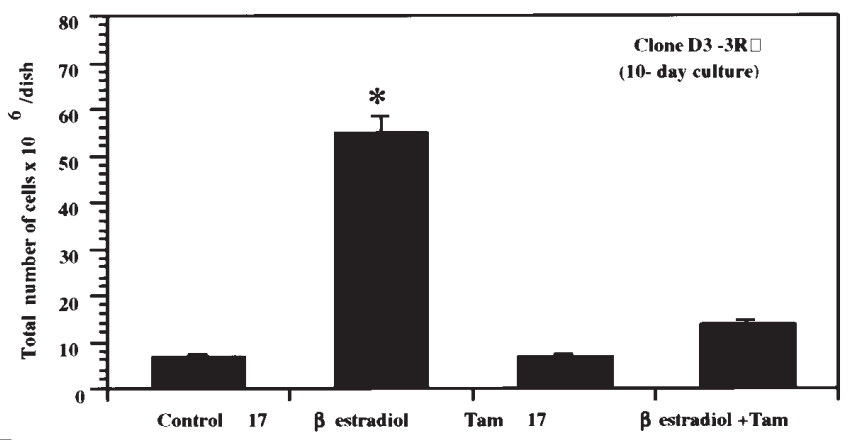

$\mathbf{E}$

Figure 5. The bars represent the mean \pm SE of total number of cells per 10/dish of the effect of several doses of 17B estradiol (A) and tamoxifen (B) on MCF-10F cell in 10-day cell culture. The bars represent the mean \pm SE of total number of cells per 10\%/dish of combination of these two substances on MCF-10F (C); D3 (D); D3-3R (E) and MCF-7 (F) in 10-day cell culture. 17ß estradiol versus control: * $\mathrm{P}<0.05$.

studies in which cells, derived from TEBs were able to form colonies by the effect of $17 ß$ estradiol. The high susceptibility of the TEBs to neoplastic transformation, previously seen in rats (32), is due to the high proliferative rate of its epithelium, as determined by the mitotic and DNA-LI indices. These indices were very high at the tip of the TEBs of the mammary gland and decreased toward the ductal or proximal portions of the rat mammary gland; and decreased in more differentiated structures such as lobules (32-34).

It has been previously shown that tissue of young women consisting of mainly intraterminal duct (ITD) or TEBs and alveoli had a DNA-LI of 1.00 while tissues of the older group consisted of large ducts, ITD ducts and alveoli with a mean DNA-LI of 0.42 (23). Hormones seem to alter the proliferative behaviour of breast tissues. It was demonstrated by DNA-LI $(23,35)$, growth fraction (GF) (36), length of $S$ phase (Ts) (37) and total cell cycle (Tc) (37) determination in response to $17 \AA$ estradiol after 5 days in culture systems. The DNA-LI and mitotic index in 5-day organ culture was significantly greater in the presence of estrogen in comparison

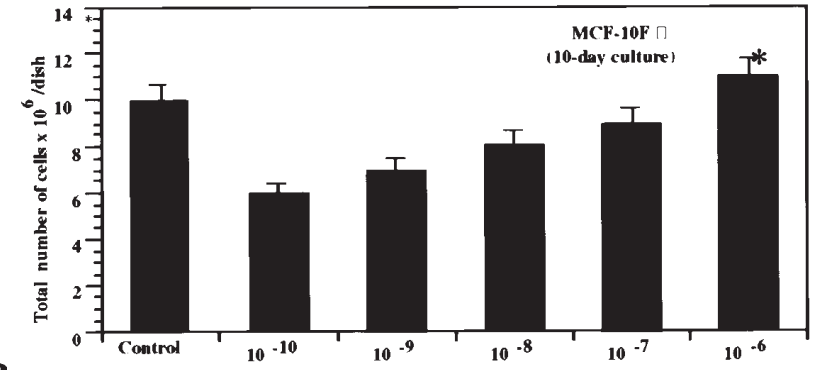

B
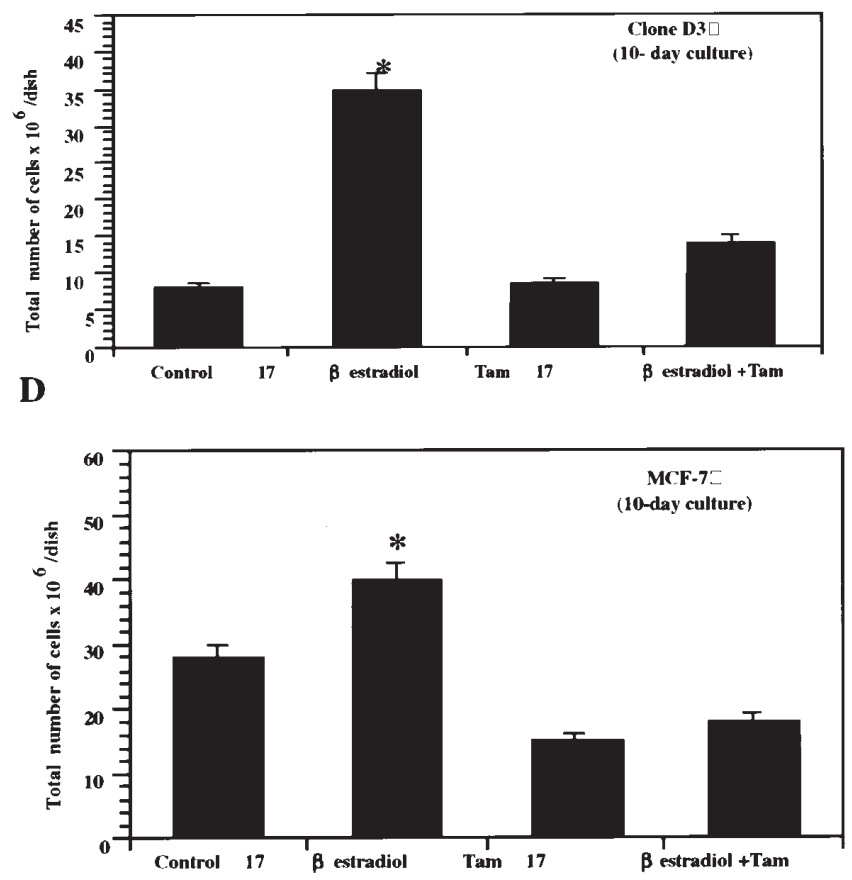

$\mathbf{F}$ to control. Welsch (38) has also shown that 173 estradiol enhanced DNA synthesis of normal breast ductal epithelium maintained in the athymic nude mouse.

We showed $(24,36)$ that $17 ß$ estradiol increased the growth fraction of mammary epithelial cells. The GF was measured to determine the effect of hormones on the total compartments of the cells engaged in the cell cycle. Such values increased from 0.18 to 0.34 in the presence of hormones, indicating that any combination of hormones may alter the cell cycle of normal breast tissue by stimulating the cells to re-enter into the cell cycle from $\mathrm{G}_{0}$. Ts was also affected by steroid hormones and known be involved in the process of mammary gland differentiation. $17 \mathrm{~B}$ estradiol seems to be most effective en lengthening Ts with a consequent in DNA synthesis. Previous studies (36) indicated that this steroid lengthened the $\mathrm{S}$ phase of normal breast cell cycle in 5-day tissue cultures from $6.42 \pm 1.9$ to $8.70 \pm 1.7 \mathrm{~h}$ in comparison with cultures without this hormone. Such increase in DNALI may be due to the lengthening of Ts or to an increment in the unscheduled synthesis, rather than to a specific mitogenic 


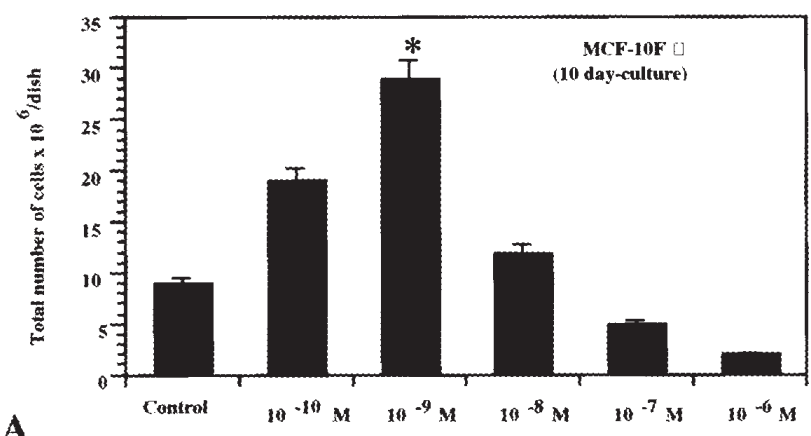

$\mathbf{A}$
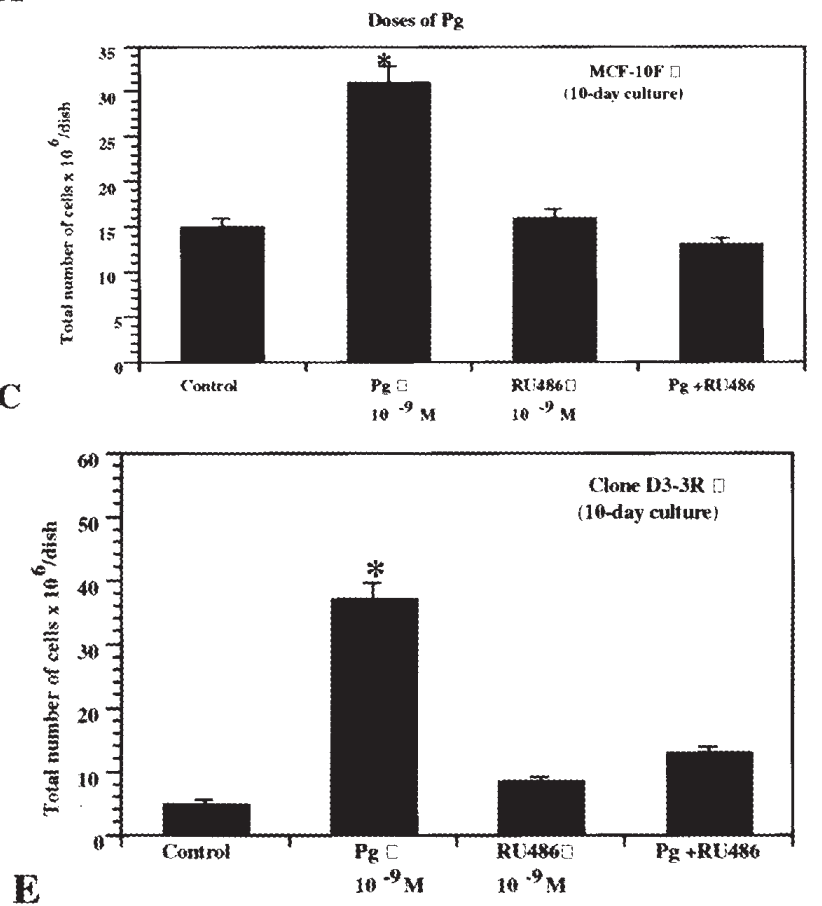
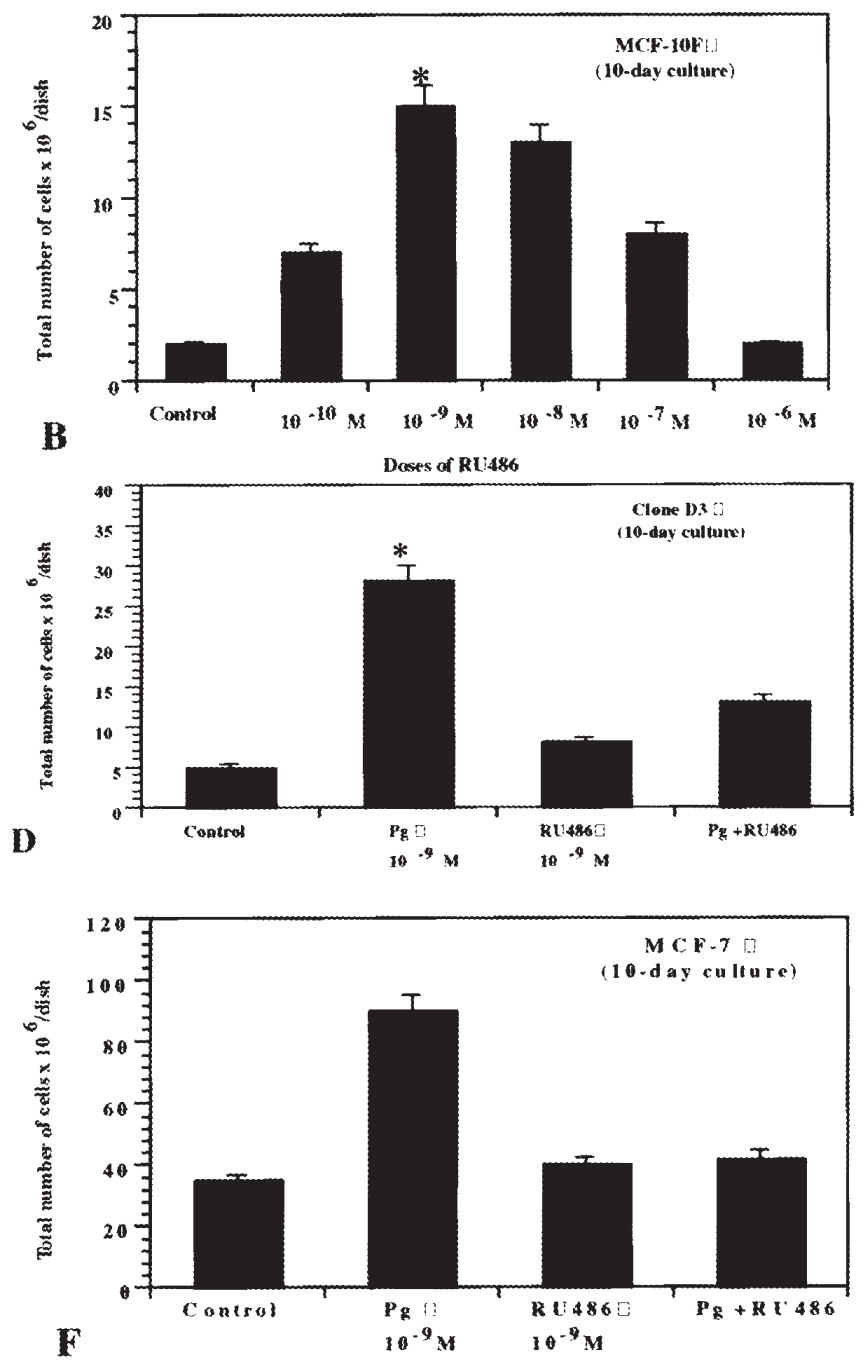

Figure 6. The bars represent the mean \pm SE of total number of cells per 10\%/dish of the effect of several doses of progesterone (A) and RU486 (B) on MCF-10F cell in 10-day cell culture. The bars represent the mean \pm SE of total number of cells per 10\%/dish of combination of these two substances on MCF-10F (C); D3 (D); D3-3R (E) and MCF-7 (F) in 10-day cell culture. 17ß estradiol versus control: ${ }^{*} \mathrm{P}<0.05$.

effect. On the other hand, the total length of the cell cycle (Tc) decreased from $291.6 \mathrm{~h}$ in the control to $34.0 \mathrm{~h}$ in the 173 estradiol-treated group (37). Hormones affect cell cycle and cells enter $\mathrm{G}_{0}$ of the cell cycle by such stimulus.

It has also been demonstrated that during the first trimester of a pregnancy, $17 ß$ estradiol concentrations rise rapidly (39). It seems that during the first part of a pregnancy, breast tissue divides very rapidly and the net effect of an incomplete pregnancy is a high degree of cell proliferation thus increasing the probabilities of developing breast cancer. Thus, a spontaneous or induced abortion during the first trimester, seems to increase breast cancer risk $(40,41)$. During puberty and adulthood the normal cyclic proliferation, influenced by estrogen-progesterone depend on the proliferation of stem cell population within the terminal ramifications of the ducts (42). Cell division increases the possibility of various genetic errors (43), thus it can be suggested that prolonged stimulation by steroid hormones may induce breast cancer (44).

Proliferative capability of $17 ß$ estradiol was studied on epithelial cells and the fibroblasts present in fibrocystic disease, in comparison to control after 5 days in culture (35). The effect of $17 ß$ estradiol on cell proliferation was determined in benign lesions, that is fibrocystic disease and fibroadenomas (35). Estrogen increased DNA synthesis as shown by DNA$\mathrm{LI}$ and $\left[{ }^{3} \mathrm{H}\right]$ thymidine incorporation into DNA in fibrocystic lesions. DNA synthesis was increased in epithelial cells as well as fibroblasts of fibrocystic disease lesions after 5-day cultures in comparison to control ones. However, fibroblasts and epithelial cells present in tissues derived from fibroadenomas showed very similar trend to those for fibrocystic disease, but did not reach significance in comparison to control. Studies have pointed out that specific components of benign breast diseases, collectively called 'proliferative disease(s)' and progression of this disease has been associated with an increased risk for breast cancer (45).

Epidemiological research and evidence $(1,46,47)$ indicate that the susceptibility of breast tissue to alter human breast lesion is related with hormonal imbalance and proliferative diseases. It has been reported that women with breast cancer have a high amount of free $17 ß$ estradiol in the blood that provides the growth stimulus for the tumor (48). Such finding 
have been supported and refuted (49) because reduction in free (active) estradiol concentrations can lead to a decrease in breast cancer risk. Similarly, it has been suggested that increased $17 ß$ estradiol concentrations achieved by hormone replacement therapy or oral contraceptive use would also increase the risk. Thus, one possible mechanism for breast cancer development is the consequence of excessive estrogenic stimulation that induces excessive cell proliferation of normal breast epithelial tissue (2-50). More specifically, the malignant phenotype is developed through errors in cell division (DNA copying errors, translocations) (51). Therefore, estrogen is also known to control the growth of many carcinomas in experimental animals and humans (5).

The basis of endocrine treatments for breast cancer is based upon estrogen effect. It was of interest to compare the effect of $17 ß$ estradiol and tamoxifen on cell proliferation of immortalized normal and malignant epithelial human breast cell lines. Tamoxifen has proven to be as effective in the treatment of hormone-dependent breast cancer as any ablative or additive therapy. DNA synthesis of malignant lesions in culture indicated that $17 ß$ estradiol increased DNA-LI and $\left[{ }^{3} \mathrm{H}\right]$ thymidine incorporation into DNA in comparison to control. However, tamoxifen and combination of $17 ß$ estradiol and tamoxifen inhibited such effect in comparison to $17 \mathrm{~B}$ estradiol treatment alone. We have previously shown that $17 ß$ estradiol stimulated DNA synthesis of malignant lesions (carcinomas in situ) of pre- and postmenopausal women after 5 days in culture, as well as the $\left[{ }^{3} \mathrm{H}\right]$ thymidine incorporation into DNA both type of women in comparison to controls (25).

Even though the MCF-10F cells were estrogen receptor negative, they were very sensitive to estrogen at $10^{-8}$ since cell proliferation increased (1.6-fold increase) after 10 days. Addition of $17 ß$ estradiol of a $10^{-8} \mathrm{M}$ and tamoxifen at $10^{-6}$ dose to the immortalized MCF-10F cells, respectively gave similar results to the malignant carcinomas in vitro since it was found that $17 ß$ estradiol increased cell proliferation in comparison to control. However, tamoxifen alone and combination of both inhibited such effect when compared to $17 ß$ estradiol alone. The clone D3 was stimulated by $17 \beta$ estradiol at $10^{-8} \mathrm{M}$ (4-fold increase) and tamoxifen inhibited such growth at $10^{-6} \mathrm{M}$ in the same magnitude in comparison to control. There was non-significant difference between tamoxifen and $17 ß$ estradiol plus tamoxifen-treated group. The clone D3 was irradiated with $3 \gamma$ ray doses and the cell line was named clone D3-3R, it was stimulated by $17 \mathrm{~B}$ estradiol at $10^{-8} \mathrm{M}$ (10-fold increase) and tamoxifen inhibited such growth at $10^{-6} \mathrm{M}$ in comparison to control.

The malignant human breast epithelial cell line MCF-7 was stimulated by $17 \mathrm{~B}$ estradiol at $10^{-8} \mathrm{M}$ (1.4-fold increase) and tamoxifen inhibited such growth at $10^{-6} \mathrm{M}$ (2-fold increase) in comparison to control. In this report we showed that tamoxifen inhibited the effects of 173 estradiol on DNAsynthesis in carcinomas derived from premenopausal women after 5 days of culture. Treatment with tamoxifen seems to block the estrogenic activity, as shown with MCF-7, the human breast cancer cell line. This cell line when growing in medium without $17 \beta$ estradiol exhibited low progesterone receptor level but the addition of this hormone stimulated the amount of such receptors; tamoxifen inhibited such stimulation (52). Our previous work demonstrated that 173 estradiol increased cell proliferation and $\left[{ }^{3} \mathrm{H}\right]$ thymidine incorporation into DNA in JCK and GCS cells lines derived from pleural effusion and ascitic fluid, respectively (53). Hormones, especially estrogens, have been linked to breast cancer $(34,54-59)$ and their role has been attributed to their ability to stimulate cell proliferation, which in turn leads to accumulation of random genetic errors that result in neoplasia (4).

In the mature cycling animal, tamoxifen acts as an antiestrogen causing atrophy of lobular structures (57). This drug has been used as a long-term adjuvant therapy (58) and for prevention of human breast tumor recurrence after lumpectomy in women with invasive breast cancers of $\leq 1 \mathrm{~cm}$ (16). Murphy et al (59) have found that inducible up-regulation of estrogen receptor $\beta$ affects estrogen and tamoxifen responsiveness in MCF-7 human breast cancer cells.

The tumorigenic response of carcinogens is maximal when it is administered to undifferentiated and highly proliferating structures. Thus, hormonal pattern of breast in young premenopausal women seems to render it particularly vulnerable to carcinogenesis $(24,35)$. Different in vitro model systems of normal breast, benign and malignant lesions, together with pleural effusions and ascitic fluids of breast cancer patients have allowed to perform cell proliferation studies to answer these questions $(24,25,60)$. Identification of factors involved in cell proliferation has been facilitated by studies using breast cancer cell lines representative of different tumor phenotypes. New model systems in which the effects of carcinogens (29) or high LET ionizing radiation and estrogen (31) have transformed the immortalized cell line MCF-10F are available for analyzing breast carcinogenesis. We found a stimulatory effect of $\alpha$ particle radiation and estrogen on cell transformation. MCF-10F cells, irradiated with single and double doses of $60 \mathrm{cGy} \alpha$ particles and subsequently treated with estrogen, showed gradual phenotypic changes including altered morphology, increased cell proliferation relative to control, anchorageindependent growth, invasive capabilities and tumorigenicity in nude mice. MCF-10F cells irradiated with a second dose of 60 cGy a particles after estrogen treatment $(60 \mathrm{cGy}+\mathrm{E} /$ $60 \mathrm{cGy}+\mathrm{E}$, named Alpha 5) showed tumorigenicity both in SCID and nude mice (31).

Estrogens, acting in the presence of exogenous initiators (e.g., ionizing radiation and chemical carcinogen) stimulates cell growth resulting in hyperplasia and neoplasia. Therefore, breast cancer development is a function of cumulative estrogen exposure and the consequent mitotic activity and the increased probabilities of DNA synthetic errors. It has been suggested that the proliferative capability of breast tissue is essential in cell transformation. It can be concluded from the present study that hormones as estrogens should be carefully controlled in women with proliferative diseases and those subject to hormone replacement in postmenopausal women. Continuous stimulation by hormones may increase cell proliferation and thus increasing the possibility of cell transformation leading to breast cancer.

\section{Acknowledgements}

Sincere thanks are due to Sarah E. Baker for her critical reading of the manuscript and Danissa Barahona for her 
administrative work. Dr C.V. Jordan and Dr W.H. Catherino are acknowledged for providing the drug RU486. The grant support given by UTA 4714-04 and FONDECYT 1040300 is greatly appreciated.

\section{References}

1. Krieger N: Exposure, susceptibility, and breast cancer risk: a hypothesis regarding exogenous carcinogens, breast tissue development, and social gradients, including blacklwhite differences, in breast cancer incidence. Breast Cancer Res Treat 13: 205-223, 1989.

2. Henderson BE, Ross R and Bernstein L: Estrogens as a cause of human cancer: the Richard and Hinda Rosenthal Foundation award lecture. Cancer Res 48: 246-253, 1988.

3. Feigelson HS, Ross RK, Yu MC, Coetzee GA, Reichardt JK and Henderson BE: Genetic susceptibility to cancer from exogenous and endogenous exposures. J Cell Biochem Suppl 25: 15-22, 1996.

4. Henderson BE, Ross RK and Pike MC: Hormonal chemoprevention of cancer in women. Science 259: 633-638, 1993.

5. Huseby RA: Methods in Hormone Research. Dorfman RV (ed). Academic Press, New York, p123, 1965.

6. Dickson RB and Lippman ME: Estrogenic regulation of growth and polypeptide growth factor secretion in human breast carcinoma. Endocr Rev 8: 29-43, 1987.

7. Petrakis NL, Ernster VL and King MC: Breast. In: Cancer Epidemiology and Prevention. Schottenfeld D and Fraumeni JF Jr (eds). WB Saunders, Philadelphia, pp855-870, 1982.

8. Jordan VC: Chemoprevention in the 21st century: is a balance best or should women have no estrogen at all? J Clin Oncol 23: 1598-1600, 2005.

9. Cole MP, Jones CT and Todd ID: A new anti-oestrogenic agent in late breast cancer. An early clinical appraisal of ICI46474. Br J Cancer 25: 270-275, 1971.

10. Tormey DC and Jordan VC: Long-term tamoxifen adjuvant therapy in node-positive breast cancer: a metabolic and pilot clinical study. Breast Cancer Res Treat 4: 297-302, 1984.

11. Tormey DC: Long-term adjuvant therapy with tamoxifen in breast cancer: how long is it? Ann Intern Med 106: 762-764, 1987.

12. Early Breast Cancer Trial List' Collaborative Group: Effects of adjuvant tamoxifen and of cytotoxic therapy in early breast cancer: an overview of 61 randomized trails among 28,896 women. N Engl J Med 319: 1681-1692, 1988.

13. Jordan VC: Long-term adjuvant tamoxifen therapy. In: Important Advances in Oncology. De Vita UT, Hellman S and Rosemberg SA (eds). Lippincott, Philadelphia, 1989.

14. Jordan VC: Antiestrogens and selective estrogen receptor modulators as multifunctional medicines. 1. Receptor interactions. J Med Chem 46: 883-908, 2003.

15. Jordan VC: Antiestrogens and selective estrogen receptor modulators as multifunctional medicines. 2. Clinical considerations and new agents. J Med Chem 46: 1081-1111, 2003.

16. Fisher B, Bryant J, Digman JJ, Wickerham DL, Mamounas EP, Fisher ER, Margolese RG, Nesbitt L, Paik S, Pisansky TM and Wolmark N: Tamoxifen, radiation therapy, or both for prevention of ipsilateral breast tumor recurrence after lumpectomy in women with invasive breast cancers of one centimeter or less. J Clin Oncol 20: 4141-4149, 2002.

17. Moguilewsky M and Philibert D: RU 38486: potent antiglucocorticoid activity correlated with strong binding to the cytosolic glucocorticoid receptor followed by and impaired activation. J Steroid Biochem 20: 271-276, 1984.

18. Philibert D, Moguilewsky M, Mary I, Lecque D, Touremine C, Secchi J and Deraedt R: Pharmacological profile of RU 486 in animals. In: The Antiprogestin Steroid RU 486 and Human Fertility Control. Baulieu E-E (ed). Plenum Publishing Co., New York, pp49-68, 1985.

19. Rauch M, Loosfelt H, Philibert D and Milgrom E: Mechanism of action of an antiprogesterone, RU486, in the rabbit endometrium. Effects of RU486 on the progesterone receptor and on the expression of the uteroglobin gene. Eur J Biochem 148: 213-218, 1985.

20. Spitz IM and Bardin CW: Mifepristone (RU 486) a modulator of progestin and glucocorticoid action. N Engl J Med 329: 404-412, 1993.

21. Spitz IM: Progesterone antagonist and progesterone receptor: an overview. Steroids 68: 981-993, 2003.
22. Stampfer M, Hallowes RC and Hackett AJ: Growth of normal human mammary cells in culture. In Vitro 16: 415-425, 1980.

23. Calaf G, Russo IH, Roi L and Russo J: Influence of age on DNA labeling index of human breast epithelium. IRCS Med Sci 10: 657-658, 1982.

24. Calaf G, Russo IH and Russo J: Effects of peptides and steroid hormones on cell kinetic parameters of normal human tissue in organ culture. In Vitro Cell Dev Biol 22: 135-140, 1986.

25. Calaf G, Garrido F, Moyano C and Rodriguez R: Influence of hormones on DNA synthesis of breast tumors in culture. Breast Cancer Res Treat 8: 223-232, 1986.

26. Soule HD, Maloney TM, Wolman SR, Petersen WD Jr, Brenz R, McGrath CM, Russo J, Pauley RJ, Jones RF and Brooks SC: Isolation and characterization of a spontaneously immortalized human breast epithelial cell line, MCF-10. Cancer Res 50: 6075-6086, 1990.

27. Calaf G, Russo J, Tait L, Estrada S and Alvarado ME: Morphological phenotypes in neoplastic progression of human breast epithelial cells. J Submicrosc Cytol Pathol 32: 83-96, 2000.

28. Calaf G, Russo J and Alvarado ME: Morphological phenotypes in neoplastic progression of benz(a)pyrene-treated breast epithelial cells. J Submicrosc Cytol Pathol 32: 535-545, 2001.

29. Calaf $G$ and Russo J: Transformation of human breast epithelial cells by chemical carcinogens. Carcinogenesis 14: 483-492, 1993.

30. Soule HD, Vazguez J, Long A, Albert S and Brennan M: A human cell line from a pleural effusion derived from a breast carcinoma. J Natl Cancer Inst 51: 1409-1416, 1973.

31. Calaf G and Hei TK: Establishment of a radiation- and estrogeninduced breast cancer model. Carcinogenesis 21: 769-776, 2000.

32. Russo J and Russo IH: DNA-labeling index and structure of the rat mammary gland as determinants of its susceptibility to carcinogenesis. J Natl Cancer Inst 61: 1451-1459, 1978.

33. Russo J and Russo IH: Influence of differentiation and cell kinetics on the susceptibility of the rat mammary gland to carcinogenesis. Cancer Res 40: 2677-2687, 1980.

34. Russo J and Russo IH: Toward a physiological approach to breast cancer prevention. Cancer Epidemiol Biomarkers Prev 3: 353-364, 1994.

35. Russo J, Calaf G, Roi L and Russo IH: Influence of age and gland topography on cell kinetics of normal human breast tissue. J Natl Cancer Inst 78: 413-418, 1987.

36. Calaf G, Russo IH, Roi L and Russo J: Effect of estrogen on the length of S phase of human breast tissue. IRCS Med Sci 10: 307-308, 1982.

37. Calaf G, Russo IH, Roi L and Russo J: Effect of hormones on growth fraction of human breast tissue in organ culture. IRCS Med Sci 10: 655-656, 1982.

38. Welsch CW: Host factors affecting the growth of carcinogeninduced rat mammary carcinomas: a review and tribute to Charles Brenton Huggins. Cancer Res 45: 3415-3443, 1985.

39. Bernstein L, Depue RH, Ross RK, Judd HL, Pike MC and Henderson BE: Higher maternal levels of free estradiol in first compared to second pregnancy: early gestational differences. J Natl Cancer Inst 76: 1035-1039, 1986.

40. Hadjimichael OC, Boyle CA and Meigs JW: Abortion before first livebirth and risk of breast cancer. Br J Cancer 3: 281-284, 1986.

41. Pike MC, Henderson BE, Casagrande JT, Rosario I and Gray GE: Oral contraceptive use and early abortion as risk factor for breast cancer in young women. Br J Cancer 43: 72-76, 1981.

42. Potten CS: Stem Cells. Their Identification and Characteristics. Churchill-Livingstone, Edinburgh, 1983.

43. Loeb LA: Mutator phenotype may be required for multistage carcinogenesis. Cancer Res 51: 3075-3079, 1991.

44. Bernstein L and Ross RK: Endogenous hormones and breast cancer risk. Epidemiol Rev 15: 48-65, 1993.

45. Henderson BE, Pike MC and Ross RK: Epidemiology and risk factors. In: Breast Cancer: Diagnosis and Management. Bonadonna G (ed). John Wiley and Sons, Ltd., New York, 1984.

46. Lippman ME, Osborne CK, Knazek R and Young N: In vitro model systems for the study of hormone-dependent human breast cancer. N Engl J Med 296: 154-159, 1976.

47. Dickson MB and Lippman ME: Control of human breast cancer by estrogen, gene factors and oncogenes. In: Breast Cancer: Cellular and Molecular Biology. Lippman ME and Dickson RB (eds). Kluwer Academic, Norwell, MA, pp119-166, 1988. 
48. Siiteri PK, Hammond GL and Nisker JA: Increased bioavailabitity of serum estrogens in breast cancer: a new hypothesis. In: Hormones and Breast Cancer, Banbury Report 8. Pike MC, Siiteri PK and Welsch CW (eds). Cold Spring Harbor Laboratory, New York, 1981.

49. Fentiman IS: Detection and Treatment of Early Breast Cancer. JB Lippincott, Philadelphia, 1990.

50. Preston-Martin S, Pike MC, Ross RK, Jones PA and Henderson BE: Increased cell division as a cause of human cancer. Cancer Res 50: 7415-7421, 1990.

51. Cairns J: Mutation selection and the natural history of cancer. Nature 255: 197-200, 1975.

52. Welshons WV, Murphy CS, Kock R, Calaf G and Jordan VC: Stimulation of breast cancer cells in vitro by the environmental estrogen, enterolactone and the phyto-estrogen equol. Breast Cancer Res Treat 10: 169-175, 1987.

53. Calaf G, Abarca-Quiñones J, Feuilhade F, Beaune J, Dupre G, Orrico M, Barnabas-Sohi N and Kouyoumkjian JC: New cell lines of human breast cancer origin. Breast Cancer Res Treat 21: 63-75, 1992.

54. Henderson BE, Ross RK, Pike MC and Casagrande JT: Endogenous hormones as a major factor in human cancer. Cancer Res 42: 3232-3239, 1982.
55. Furr BJ and Jordan VC: The pharmacology and clinical uses of tamoxifen. Pharmacol Ther 25: 127-205, 1984.

56. Nicholson RI, Gotting KE, Gee J and Walker KJ: Actions of oestrogens and anti-oestrogens on rat mammary gland development: relevance to breast cancer prevention. J Steroid Biochem 30: 95-103, 1988.

57. Gotze S, Nishino Y and Neumann F: Anti-oestrogenic effects of tamoxifen on mammary gland and hypophysis in female rats. Acta Edocrinol Copenh 105: 360-370, 1984.

58. Jordan VC: Tamoxifen for breast cancer prevention. Proc Soc Exp Biol Med 208: 144-149, 1995.

59. Murphy LC, Peng B, Lewis A, Davie JR, Leygue E, Kemp A, Ung K, Vendetti $M$ and Shiu R: Inducible upregulation of oestrogen receptor-\{beta\} 1 affects oestrogen and tamoxifen responsiveness in MCF7 human breast cancer cells. J Mol Endocrinol 34: 553-566, 2005.

60. Calaf G and Hei TK: Oncoprotein expressions in human breast epithelial cells transformed by high LET radiation. Int J Radiat Biol 77: 31-40, 2001. 